\title{
"I EXIST THEREFORE YOU EXIST, WE EXIST THEREFORE THEY EXIST": NARRATIVES OF MUTUALITY BETWEEN DEITIES (YUL-LHA GZHI BDAG) AND LHOPO (BHUTIA) VILLAGERS IN SIKKIM ${ }^{1}$
}

\author{
Kikee D. Bhutia \\ Doctoral student \\ Department of Estonian and Comparative Folklore \\ University of Tartu, Estonia \\ e-mail:keylabhutia@gmail.com
}

\begin{abstract}
This article engages with the presence, personalities, and lives of $y u l$ lha gzhi bdag (protective and guardian deities) who reside with the Lhopo (Bhutia) community in Sikkim, India. Informed by fieldwork, and through narratives, observations, and experiences, I illustrate and discuss how interactions and connections between villagers and deities are shaped by principles of relationality and mutuality. After discussing the various meanings and manifestations yul lha gzhi bdag take on in diverse Himalayan contexts, I illustrate through discussions of rituals, practices, beliefs, and narratives how the 'mundane' routines and lifeworld of the Lhopo villagers variously connect with, and derive meaning from, the supernatural world that surrounds them. I argue, however, that this is not a one-way process but that deities similarly rely on villagers to derive and validate their existence in the world. This mutuality, however, increasingly finds itself under strain as a result of social processes of modernity, globalization, changing relations with land, religious conversion, and competing forms of educational and medical knowledge, on which I reflect in the conclusion.
\end{abstract}

Keywords: Buddhism, everyday practices, mutuality of being, narratives, yul lha gzhi bdag (guardian deities)

\section{INTRODUCTION}

"If you put your hands into a beehive, it will hurt, right? Your research is like putting your hands into a beehive," a senior monk warned me after I had told him I wished to research the yul lha gzhi bdag (guardian deities). Among the Lhopos (Bhutias), guardian deities are many, manifold in character, and mired into often competing narratives. Anna Balikci (2008: 85), in her book Lamas, 
Shamans and Ancestors: Village Religion in Sikkim, wrote, based on her interviews with Lopen Dugyal, who happens to be my grandfather, that "there are many more spirits and deities inhabiting the environment in Sikkim than there are human beings".

This article ventures into this densely populated supernatural landscape to explore the relational practices and beliefs that connect these spirits and deities with villagers. I do so through the vantage of narratives, as they are told and re-told in the small Lhopo village of Tingchim in northern Sikkim. I begin by narrating a personal experience told to me by a villager (male, 52 years old, 2016) ${ }^{2}$ :

I went to pick Daw's aba-ama's [father and mother's] cardamom in their field. It is just there, near that little forest area [pointing with his finger]. It was not that long ago. Perhaps five or six years. I was picking cardamom near the stream. Our village was on the other side of the river. To my right was Zyashing Aju [the guardian deity who resides there]. While collecting cardamom and slowly shifting down the field, I inched closer to Zyashing Aju [Aju translates as "old man" or "grandfather"]. I noticed that the cardamom plants were very healthy in that area. Then I said bluntly: "Oh, today I have come near our neighbor Zyashing Aju, but it seems he does not even want to greet us?" I was not alone that day. Many other workers were there, and I said it in a joking manner. We all laughed. That night my waist was in terrible pain. Zyashing Aju shi-je [caught, attacked]. I had to perform a sdè chey [offering to the sdè ${ }^{3}$ to appease him. Only after that I returned to my normal self. This was how Zyashing Aju greeted me back.

My informant related the pain he felt in his waist immediately to his, somewhat mischievous, interference in the abode of Zyashing Aju earlier that day. He realized that his taunting, even if meant light-heartedly, had angered the deity into inflicting punishment. My informant knew that the only way for him to get cured now was to propitiate Zyashing Aju through a ritual offering. What this opening narrative illustrates is, among others, that yul lha gzhi bdag are an intricate part of village life - both in articulations (villagers addressing them) and acts (villagers propitiating them).

In Tingchim, and Lhopo villagers more widely, such personal narratives, experiences, and stories serve to actualize the supernatural world and therefore impact the way villagers perceive these worlds. Cristina Bacchilega (2015: 28) writes: 
Stories construct our worlds and us at the same time, emerging from actual negotiations with and in these worlds. Stories create and weave together the social networks that define us whether we belong to them or we other them. Stories shape our conceptions of these worlds, and they have material impact on these worlds, the human ones and the other living ones (natural and spiritual) we are a part of.

That stories help to construct the world around us, both mundane and supernatural, became evidently clear to me while I was conducting fieldwork and gathering belief narratives in 2016-2017. My aim was, first, to document circulating narratives of yul lha gzhi bdag, and, secondly, to understand the interaction and relationships that exist between these deities and villagers. Put differently, I wanted to explore how the everyday, mundane world of Tingchim villagers connects with, and is shaped by, the supernatural world surrounding them.

In what follows I apply belief narratives to describe and discuss the dyadic relationships that exist between deities and villagers. Oftentimes, I will illustrate, villagers portray a certain fear, or certainly apprehension, of offending deities, knowing that deities, once angered, can exert various forms of punishment, including sickness, insanity, and premature death. What I will argue here, however, is that deities inflicting such punishments may also be seen as communicative of deities' own fears of being forgotten by the villagers, their apprehension of not being acknowledged through offerings and sacrifices. These feelings of mutual fear, however, do not suggest relations of hostility and impending danger, but are reflective of - and herein lies the main argument of this article - the "mutuality of being" that is constitutive of the identities, indeed the very existence, of both deities and villagers. As a way of seeing kinship, Sahlins (2013: 18-20) describes the "mutuality of being" as the "participation in another's existence", as "conjoint being", and "interdependent existence". Transposing this argument to the relationships between deities and villagers, I will illustrate that they share a close interconnectedness and sense of shared existence and belonging.

\section{YUL LHA GZHI DAG: A BRIEF INTRODUCTION}

The phenomenon of yul lha gzhi bdag has been classified and theorized differently in different parts of the Himalayas, where their existence is widely reported. But one of the most accepted explanations remains that the yul lha gzhi bdag are the untamed deities of the land who were bounded into the oath by Guru Rinpoche, who is also known as the second Buddha in the eighth cen- 
tury. In Tibet, to start with, Réne de Nebesky-Wojkowitz (1993: 15) explains yul lha as "country gods" and gzhi bdag as "foundation owners", citing Giuseppe Tucci (1980 [1949]:

It appears that these classifications do not cover all the great variety of spirits, ghosts, demons, gods in which Tibetans believed. The character of these beings was in many cases so vague that it was very difficult to establish demarcation between them. Even the place they were supposed to dwell is not enough to establish a clear distinction between the various classes of gods: for lack of individuality these divine groups tended to blend together.

Samten G. Karmay (1998: 66), writing in the context of mountain deities in Tibet, translates yul lha as "deity of the local territory", and justifies this by translating $y u l$ as "local", citing terms such as yul-dpon (local chief), yul skad (local dialect), and $y u l ~ m i$ (local people) to his support. Valentina Punzi (2013: 73) similarly argues that the worship of yul lha gzhi bdag is best understood as "the cult of mountain dwelling local numina", and translates the term yul lha as the "deity of the local territory". Katia Buffetrille, in turn, translates yul lha as "Territorial God" (Buffetrille 1996: 6). Françoise Pommaret (2012: 4), in the context of Bhutan, highlights a certain vagueness surrounding this term. She, however, settles on the position of gzhi bdag as "master of the place", but reiterates how the relationship between a "dgra lha (mountain god) and a yul lha (territorial god) is quite blurry". She continues: "The whole issue of definitions is all the more complex today, as recent extensive fieldwork in the Himalayas has shown significant variations from region to region among deities referred to by the same generic term" (ibid.).

These classifications and explanations are derived from areas surrounding Sikkim, specifically from Tibet and Bhutan. I now discuss the meaning of $y u l$ lha gzhi bdag in the context of Sikkim, especially for the Lhopos (Bhutias). In the social context of Tingchim, and according to one of my informants (male, 72 years old, 2016), yul lha gzhi bdag must be distinguished into two categories: benevolent ye shes kyi lha (also known as sang gye kyi lha), and dangerous jig rten kyi lha. ${ }^{4}$ In simple terms, ye shes kyi lha refers to enlightened deities (lha) who belong to the Buddhist ritual. Among these ye shes kyi lha, Dzönga ${ }^{5}$, who resides on Mount Khanchendzönga, ${ }^{6}$ is considered as "a supra-worldly deity of the Buddhist pantheon (ye shes lha)" (Balikci 2008: 90).

One of the main characteristics of the ye shes kyi lha, as one of my interlocutors (male, 58 years old, 2016) explained, is: "They do not inflict sickness on people. They do not harm them. Instead they are Dharma protectors [protector 
of Buddhist doctrines and teachings] and were subdued by Guru Rinpoche himself." Most informants explained that Guru Rinpoche himself is a ye shes kyi lha.

Jig rten kyi lha, on the other hand, are considered as "unenlightened gods", or the gods of the temporal world (jig rten can translate as "worldly" or "lay people"). Contrary to ye shes kyi lha, these "unenlightened deities" are known and feared for inflicting sickness and misery when offended. Besides causing sickness, they, for instance, possess powers to disrupt rainfall, causing great loss to villagers as this affects the quality and quantity of harvests. This interpretation opens the possibility of $y u l$ meaning "worldly" or the god (deity) of the "lay people". One informant explained: "They cannot show us the path to enlightenment but they can determine our well-being and prosperity while we are in this world."

This separation of deities as either Dharma protectors or "worldly" relates, more deeply, to the advent of Buddhist teachings and philosophy in Sikkim. Most of the ritual specialists and monks in Sikkim argue that yul lha gzhi bdag were subdued by Guru Rinpoche around the eighth century when he visited Sikkim on his way to Tibet. This also seems the case in Bhutan and Tibet as it is believed that yul lha gzhi bdag were present in the land well before the arrival of Guru Rinpoche, but, on Guru Rinpoche's command, changed character and transformed into guardians and protectors of the land (Phuntsho 2013: 84). In exploring the past and presence of the yul lha gzhi bdag, and their relationship with human beings, I draw significantly on belief narratives and personal experiences as told by villagers.

\section{YUL LHA GZHI BDAG AND THE "BUDDHIST TURN"}

As I inquired into the relationship between deities and the arrival of Buddhism, one of my informants (male, 61 years old, 2017) said:

In Denjong we had numerous sdé and simu [malevolent spirits]. When Guru Rinpoche came, he not only subdued them but also bound them into an oath, turning them into protectors of the land. He purified the land and made it a sacred Buddhist place and made them the daku [owner, keeper, master].

Most of my informants portrayed a collective memory of the yul lha gzhi bdag being present in the land long before the advent of Buddhism. One of them (male, 58 years old, 2016) explained: "Yul lha gzhi bdag are neither Bon nor Buddhist. I exist therefore you exist; we exist therefore they exist. They exist just as we [humans] exist." Another informant (male, 72 years old, 2017) added: "We have 
been offering to them for a long time. Even before your great-great-grandfather was born, and even before we had any monks and monasteries in the village."

With reference to the advent of Buddhism in Tingchim, Anna Balikci (2008: 56) writes that Tingchim villagers received the first major Buddhist influence that present villagers can remember from the Lachen Gomchen (Rinpoche). ${ }^{7}$ She continues:

From his retreat above Tingchim, he is said to have prevented pawo's and nejum's [shamans] from being born in all the surrounding villages. He told villagers that with their drums and bells, the pawo and nejum kept waking up the nöpa, the ambiguous supernatural beings of the locality who could otherwise sleep for many decades if left undisturbed.

In Tingchim, villagers mostly remember the pre-Buddhist presence of the $y u l$ lha gzhi bdag by invoking narratives of baitsi natsi (annual offerings). ${ }^{8}$ What their narratives variously emphasize is the integration of pre-existent deities into the practices and beliefs of everyday Buddhism. The advent of Buddhism reshaped stories, narratives, rituals, and, as we have seen, the roles of the deities.

After the arrival of Buddhism, the way villagers interpreted and engaged deities started to change first through the kinds of offerings and rituals that were performed. I remember my mother falling seriously ill. After a divination by a (non-Buddhist) shaman, a black hen was killed as an offering, and later became our dinner. Just a few years later, however, such 'blood sacrifices' largely vanished and were replaced by the offering of bones. In fact, while having dinner, we were not allowed to throw away any bones but had to collect them for such occasions. Offerings thus changed from animals to their bones. One villager (male, 52 years old, 2016) explained: "Earlier we offered them ribs and the hind leg of an ox, but later, and because I am a monk now, I offer 'dyõe' (red thread)." Presently, most rituals are no longer performed by shamans but by village monks to the extent that some of the new shamans do not get possessed; neither are they hereditary as it used to be but now they are hired or chosen collectively by the village elders to perform the duties of the shamans and Bongthing (in special cases with Lachung, North Sikkim). Instead of animal sacrifice, rituals of tshi tha (in which the animal is either set free in the wild or domesticated not to be killed or sold) is practiced, which can be seen as an element of Buddhist influence. It was the Buddhist philosophy of compassion that resulted in this conversion from animal sacrifices to offerings of sur (milk, rice, and incense). This shift can be read as a transfer of authority of the ritual performers, in this case from pawo and nejum to Buddhist monks and village elders. 
Today, not only are pawos and nejums declining in numbers, but potential new shamans often go unrecognized. Recently, a girl in Tingchim showed signs of possession but the possibility of recognizing her as nejum was difficult for two reasons. Firstly, there were no elders and experienced pawos in the vicinity to recognize and train her. Secondly, she herself sought help and explanation from a Christian neighbor in the village, who interpreted her condition in terms of devil possession. This sparked anger among the villagers, resulting in her family's ex-communication from village activities.

Regarding the relationship between Buddhism and local deities, one of my interlocutors (male, 68 years old, 2017) narrated:

There are two kinds of yul lha gzhi bdag. Those who were there from the start and those recently arrived [transformed]. They are non-human and we are human. But just as we work during the day to take care of our families and do household chores, yul lha gzhi bdag do the same at night. They too have families to take care of. These are the first type of yul lha gzhi bdag. The other type of yul lha gzhi bdag are new arrivals, or those who changed character over time. They became gzhi bdag because of bad death, especially monks who were murdered. But there are other differences. You and I cannot become gzhi bdag even if we are murdered. ${ }^{9}$ Those who became gzhi bdag were learned and powerful as they had knowledge of ritual texts and the power to influence people through their knowledge. They are not shamans but monks and learned men.

He continued:

Let me tell you a story of how, in Gelugpa, ${ }^{10}$ during the reign of the Fifth Dalai Lama in Tibet, there was a monk who achieved the pinnacle of knowledge. He was considered as very learned, even equaling Dalai Lama himself. Because of his knowledge it became feared that he might challenge the authority. He was subsequently strangled, with a khata ${ }^{11}$ being stuffed into his mouth. He was murdered [by the government]. Have you heard of this from anyone? You should have. Everybody knows. Because he was treated unjustly, he was very upset and while he was being killed, he prayed to be reborn as sdé. Soon after, he was indeed reborn in the realm of sdé, and began harming monasteries and cause havoc. No one could do anything to stop him. Not even the Fifth Dalai Lama himself. So finally, to appease him, they performed a ritual, invoked his spirit, and negotiated with an annual offering. Till today, Gelugpa(s) must offer annually and I tell you, it is not easy to get rid of them [deities]. ${ }^{12}$ 
In this section, I argued that in Tingchim village, yul lha gzhi bdag are perceived as non-human entities that resided in the village well before the advent of Buddhism. Their existence, status, and relationships with human entities, however, altered with the arrival of Buddhism. What changed, too, was the way villagers approached them and made offerings to them. Earlier shamans possessed complete authority over rituals. Shamans were powerful and made offerings in ways prescribed by tradition, which included possessions, trance, and animal sacrifices. Today, however, it is no longer shamans but predominantly monks who preside over rituals. Thus, this change in the authority over tradition led to Buddhist practices, principles, and scriptural knowledge, which resulted in the incorporation of Buddhist views into the world of yul lha gzhi bdag, transforming the status of the deities as well as their relationship with the villagers.

\section{RELATEDNESS AND MUTUALITY}

In this section, I discuss and illustrate the relational principles that connect Tingchim villagers and yul lha ghi bdag by framing their relations in an idiom of "relatedness" (Carsten 2000). I discuss what "being related" to the supernatural means for villagers, and explore the "implications and lived experience of the relatedness" (Carsten 2000: 2). One such implication is the villagers' and deities' "mutuality of being", in the sense that they "participate intrinsically in each other's existence" (Sahlins 2011: 1).

Tingchim villagers' conceptions of personhood, or "the self", cannot be disentangled from the presence of deities in their lives. In fact, in referring to deities, villagers frame them as kin and may call them aju (grandfather) or ana (grandmother). These are respectful terms, and indicate simultaneously familial intimacy and the elevated positions deities occupy in the social hierarchy of the village. But deities are not kin only in terms of kinship terminology. They are also believed to reside inside houses and with the families they belong to. Their presence offers village households a sense of security and protection.

To illustrate this further, I now turn to three different kinds of deities that, according to villagers, reside in and around the village, and discuss their specific relations to the villagers. The first kind are those that reside in nature in or around the village, in places like particular trees, streams, lakes, and fields. Secondly, there are deities that reside in houses, mostly in attics, basements, altars, or around the hearth. The third kind of deities may be typified as "personalized deities" as they attach themselves to particular individuals, and move along with them. 
"Nature deities" appear in many stories. One villager (female, 54 years old, 2016) narrated to me the following story (which is commonly told in the village):

Out there [pointing to the right from where we were sitting], is Kedo Gong [name of place]. Do you see those trees? These trees are kin to the tsomen who lives in the stream nearby. We don't want to touch anything near that place. In the past, there was a villager who cut a tree from there. Oh wait, let me think. Who was it? It was not that long ago. It was during my grandfather's time. It must have been Gochung Aju. But I am not sure whether it was aju or aju lala. I think it is aju la la (great-grandfather). Me: What is tsomen?

Tsomen is a small stream. Tsomen is also gzhi bdag, but a bad and dangerous one. Pregnant women should never go near it. If they do, the tsomen may eat up the child inside the womb, right then and there.

One day Gochung Aju went to Kedo Gong and cut a tree. The moment he brought it home, his daughter-in-law fell ill. Within a week, she died. While she was sick, a nejum [shaman] was brought home to diagnose her. She was a very powerful nejum. The nejum got possessed, and through her the tsomen spoke: "You cut my daughter-in-law, so now I am taking yours."

Tsomen evidently is a very fierce deity. But not all deities are. Another villager (male, 27 years old, 2017) narrated:

I am in timber business. In this I need to be careful as deities reside in the forest and protect these trees. They also protect us. I therefore make offerings before I cut any tree. I need to do this to protect myself, as well as those working for me. If I just cut trees, without asking the deities' permissions, they will get upset. As long as I make offerings to them, they will keep me safe. In the past, it was my grandfather's duty to appease the deities, but when I inherited the land, I inherited the deities too, and now it is my task to make offerings to them.

One day, while I was away from the village, I told my contractor to go ahead with the work. Suddenly the weather turned very bad and a thunderstorm obstructed our work. I immediately returned to the village, sensing that something was wrong. I offered sur $^{13}$ and told the deities: "Thank you so much for providing me with these precious trees. Thank you for your protection. Now I request you to protect me and my men while we cut them." Within a few minutes, the thunderstorm stopped and my men could continue their work.

These two narratives exemplify the close bonds that exist between villagers and deities. Relations between them revolve around protection and respect, but also 
revenge. The idea of revenge, as shown in the first narrative, can be compared to human emotions, thus suggesting that deities have emotional dispositions similar to humans. The second narrative shows how deities, like humankind, are traced across generations. A villager, thus, is not just related to his or her immediate father and mother, but also, by extension, to their deities, as these follow similar patterns of descent. In both narratives, the medium of offerings nourishes and connects villagers and deities.

Regarding the "house deities", villagers oftentimes invoke Palo Ana" (attic grandmother). Palo Ana refers to a guardian deity who resides in almost every village attic and is looked upon as the protector of the house, and a repository of its wealth and health. She, however, can also be demanding and vengeful, and she is feared for her powers to inflict sickness and bestow misfortune on family members who disrespect them, or do not make offerings in time. I asked a village elder (male, 68 years old, 2017), who is known as a healer, what Palo Ana was and why we kept her. He replied:

At some point I also wondered about it and asked my father. I remember being angry, telling my father: "We are already so poor, ${ }^{15}$ why must we feed a deity when we cannot even feed ourselves?" My father replied: "It is not by choice. Our forefathers were friends with Lepchas ${ }^{16}$." One day they planned to build a döh [a shed that people build in the wild to keep their animals] and keep all their cattle in the wild together, both Lepchas and Bhutias. But our ancestors Lhopos were cunning, and when the Lepchas wanted to discontinue the venture, they took the best cows and the strongest bulls and left the weak and old ones to the Lepchas. The Lepchas did not say anything, but inside they were deeply upset. They then told their deities that they had nothing to offer them any more as the best cattle had been taken away and that they would therefore best follow the Lhopos. Soon, our people started defecating blood and falling sick. Upon this, the Lhopos invited the pawo. The deities told him: "Our guardians told us to go. They told us that all their wealth was taken away, and that they have nothing to offer us. They told us not to let you live in peace." Over the years, we tried many times to get rid of the deities but this was never possible. Eventually, we decided to negotiate with them. The deities told us: "We need a place to stay and annual offerings. If you give us both we will not harm you, but instead offer our protection.”

This narrative shows, among others, the historical possibility of "transferring deities" from one community to another. It also communicates the sway villagers can have over the deities, as the deities adhered to the Lepchas' demand that they leave and follow the Lhopos. 
Finally, I present what can be called "personalized deities", particularly those deities that are considered as attached to women in the village. About one such deity, a village woman (56 years old, 2017) said:

Well, when Daw Ama [villager's sister-in-law] falls ill or suffers for longer than three days, and so without any known cause, we request the pawo or nejum to perform mõh [divination]. In most cases, this tells us that she is inflicted by her maternal deity [lha], in which case she has to go back to her maternal house to make an offering.

When I prompted and asked why Daw Ama had to go back to her maternal house, I was told:

It has never occurred in the village that one could make the offering in any other place but her maternal home. It is there where the deity resides. We can't offer to the deity anywhere else but where they reside.

She then added:

In my case too. If I fall sick and I find out that the cause is the household deity residing in my maternal house, my brother would make an offering in his house, as the makhim [the main house / house where your ancestors lived] is now passed down to him, so the duty of making the offering has passed down to him as well.

While this narrative indicates that offerings can be made either by the afflicted person herself or by a family member, they show that in both cases the offering has to be made in the maternal home, as it is here that the deity resides. As such, villagers share with their deities a clear connection of "place" and "belonging", and it transcends the patrilocal residence patterns followed by villagers. Another informant (female, 65 years old, 2017) told me:

When a woman is married off, she will usually carry with her the lha sung [a deity who protects and moves with the individual] from her maternal house [Azang khim], who will follow her to the house of her husband. She will protect and bless her, provided, of course, that she will not be careless in making offerings.

Lha sungs, however, do not follow brides in all cases, or at least not so in contemporary times. Villagers ascribe this change to "modern times". In these so-called "modern times" village girls increasingly marry in far-away cities and subsequently return to their natal village only intermittently. And rather than consulting a shaman when they fall sick, they consult doctors in a modern hospital. In doing so, they threaten the existence of deities. 
These various narratives illustrate the intimacy between human and nonhuman entities within the cosmology of Tingchim villagers. It highlights the close-knit relationships that exist between them; a relationship expressed through engagements with place and belonging.

To conclude this section, I end with a reflection of a villager (male, 72 years old, 2017):

Deities are like us humans. When they get angry they will come to fight with you. They are strong, and if you get angry and fight with them, you are sure to lose. Instead, in such a case, you need to be submissive and ask forgiveness. This will cool their tempers. Once you know how to treat them well, they will do you no harm and that we monks know very well.

\section{NARRATIVES ABOUT CHANGING CONTINUITIES}

In recent years, Tingchim village, and North Sikkim more widely, has changed significantly. Overall material development has resulted in a decreasing number of villagers today being engaged permanently in agriculture. Many villagers now work in the government sector, or have moved away from the village for purposes of education and employment. Consequently, most of the lands in the village's outskirts have been given in ädiya (lease) to immigrant Nepalese settlers. As today fewer villagers work in the fields, the fear of a bad harvest is more unfounded. It is worth asking whether this diminishing role of agriculture also correlates with the diminishing importance of deities more generally.

Another fundamental change is the arrival, and increasing popularity, of modern hospitals and medicine, resulting in villagers no longer primarily relating their afflictions to strained relations with deities. A village elder (male, 68 years old, 2017) narrated:

These days everyone believes in doctors. They don't want to take care of deities any longer. It is because villagers now avoid and ignore deities that we have not received proper rainfall for several years. It is also because of this that we are today inflicted with many diseases such as cancer. We are turning more sinful, and nowadays many villagers cheat and no longer think about dharma [good actions]. I remember Tshamkhang Aju ${ }^{17}$ telling me 'Lushey kyap lo, lushey kyap' [offer to the deities] when my daughter was suffering from severe pain in her feet. But most villages no longer think this way. 
Our deities provide us with food, clothes, and our other needs. Everything is in their hands. If they get angry, we will all fall sick and become poor. We need to offer to them. Of course, many in the village still do, but their intentions have somewhat changed. They are no longer pure in their offerings. Imagine, I place food for you on this table, but it is only when I say that it is meant for you that you will eat. This is the way villagers offer nowadays, they offer things but don't tell their deities to come and take it.

For this village elder, recent misfortune in the village is directly related to the villagers' declining consideration of their deities. For him, the villagers' denial and inability to perform rituals and offerings is the reason for all the problems befalling the village.

I also interviewed a villager (male, 56 years old, 2016) who had recently converted to Christianity, ${ }^{18}$ and asked him about guardian deities. His response was:

They are the fallen angels like Lucifer. They exist, they live among us, but we just don't acknowledge them and by doing that, whatever they do is ineffective for us. They cannot harm us because we do not believe in them.

In this case, a Christian convert consciously disowns yul-lha gzhi bdag, banishes them from his kinship network, and claims not to acknowledge them as they think their Christian beliefs are much stronger in keeping them at bay. Might this entail the death of yul-lha gzhi bdag, or, as the village elder was concerned, it only sets the stage for further misfortune to befall on the village?

\section{CONCLUSION}

This article began by discussing the diverse interpretations of the term yul tha gzhi bdag in the Himalayan region. I showed how this term has been understood differently in different places, followed by dwelling on the meaning of this term in the context of the Lhopos in North Sikkim, as well as on the "relatedness" and "mutuality of being" that connect villagers and deities. The focus here is on the narratives, on how through the stories and experiences the deities change their positions in the lives of the villagers. While collecting these narratives, I understood the emotions and beliefs of villagers retelling these stories, and discovered that the deities not only live in these lands but they are also immortalized through the story world. These stories are told not only to keep the villagers informed about the deities but often used as a "warning" against impending danger and as guides of how to propitiate and maintain a mutual relationship for mutual co-existence. 
Reflecting on the dangers that I was often warned about, I rather feel protected and supported by the yul lha gzhi bdag. The fieldwork rekindled my relationship with the deities and made me more aware that the deities are rather someone to be taken care of than something to be scared of.

\section{ACKNOWLEDGEMENTS}

This research was supported by the Dora Plus sub-activity 1.2, which is funded by the European Regional Development Fund and implemented by Archimedes Foundation. I would like to express my gratitude to Lachung and Tingchim families for extending their knowledge to me. I further thank Ülo Valk, Valentina Punzi, Aiela Anna Balikci Denjongpa, Jelle Wouters, and Perla Kværne for reviewing the article and for the additional comments. I would like to dedicate this article to Dawa Gyalpo Bhutia (2 August 1990 - 1 May 2018), without whom it would have been impossible to complete it.

\section{NOTES}

1 Winner of the ISFNR BNN 2018 Student Prize.

${ }^{2}$ Hereinafter all the informants are anonymous on request.

3 Sdé is a local term, which roughly translates as a spirit, demon, or ghost. However, it also refers to the occurrence in which a protective deity transforms into a destroyer. In such instance, an offering is needed to appease the deity into returning to its 'protecting state'.

4 There is, however, no uniformity about this amongst villagers, as I will discuss further below.

5 Dzönga is the name of the deity who is believed to be residing in Mount Khanchendzönga. He is often considered as the master or king of all other deities and subdued by Guru Rinpoche himself.

6 This mountain tallies as the third highest mountain in the world, after Mount Everest and Kakakoram (K2).

7 Lachen Rinpoche (1867-1947) was the first Rinpoche reincarnation from the place called Namok, which is the neighboring village to Tingchim. Lachen Rinpoche spent a long time in meditation in the areas around Tingchim.

8 Sikkim was considered as Buddhist Kingdom for 333 years but in Tingchim the influence of Buddhism only started in practice after the visit of Karmapa in 1910, when he altered the animal sacrifice with flour and incense. 
9 Although some of my informants also mentioned that ordinary people would turn into shen sdé - the spirits of a human turned evil after death. For example, one day I suffered from a severe headache. Upon consulting a shaman in the village, it turned out I was inflicted by the spirit of my uncle who had died a year before of a brain tumor. The difference between sdé and shen sdé is very thin. Sdé are considered as the deities who are malevolent and want to harm, but shen sdé are usually the spirits of the village (although sometimes can also be unknown) who inflict sickness. At times, if you eat in the wild, without offering the food to the shen sdé you might get stomach ache and start vomiting.

10 There are four denominations in Buddhism - Gelugpa, Kagyupa, Nyingmapa, and Shamarpa. Gelugpa tradition is the latest among the four main schools of Tibetan Buddhism, headed by His Holiness the Dalai Lama, who is known as the spiritual and temporal King of Tibet.

${ }^{11}$ A white silk scarf usually offered during weddings, celebrations, and funerals.

12 The above-mentioned story is about the assassination of Dorjee Shugden. For reference to Dorjee Shugden, please see "The Shuk-den Affairs: History and Nature of a Quarrel" by Georges Dreyfus (1999: 227-270).

${ }^{13}$ Sur-offering includes incense, butter, and rice flour.

${ }^{14}$ According to Anna Balikci (2008: 104), "Ship Anyo Pende and Gabar Pende are Lepcha grandmother spirits who live in the attics of the houses in Tingchim from where they protect the household"; in day-to-day conversation they are called Palo ana.

${ }^{15}$ One of the main reasons why villagers want to get rid of offering rituals is that they consider it very expensive, especially during the period when the harvest is not good. They have to invite the shaman, offer him food and accommodation; other people join him and they also have to be fed; in addition, there are expenses incurred for the arrangement of the ritual ingredients, which often include an animal, alcohol, etc.

${ }^{16}$ Lepchas (Rongs) are known as the 'original inhabitants' of Sikkim, whose migration is yet unknown and they oftentimes consider themselves as 'animists or nature worshippers'.

17 Tshamkhang Aju was a sesongpa - a person with the power to stop rain and hailstones, a lama who controls hailstones and rain. Sesongpas often even act as healers and doctors in the village.

${ }^{18}$ Kalu Bhutia (55 years old) was converted to Christianity on October 24, 1989. But because he settled in the town of Gangtok and merely visited the village, he had less influence on the community. Later converts included Pintso Bhutia (56 years old), who was converted on August 15, 1999, and still resides in the village. 


\section{REFERENCES}

Bacchilega, Cristina 2015. Narrative Cultures, Situated Story Webs, and the Politics of Relation. Narrative Culture, Vol. 2, No. 1, pp. 27-46. Available at https://digitalcommons.wayne.edu/narrative/vol2/iss1/, last accessed on 10 December 2018.

Balikci, Anna 2008. Lamas, Shamans and Ancestors: Village Religion in Sikkim. Leiden: Brill Academic Publishers. https://doi.org/10.1163/ej.9789004167063.i-406.

Buffetrille, Katie 1996. One Day the Mountains Will Go Away...: Preliminary Remarks on the Flying Mountains of Tibet. In: A. Blondeau \& E. Steinkellner (eds.) Reflections of the Mountain: Essays on the History and the Social Meaning of the Mountain Cult in Tibet and the Himalaya. Wien: Verlag der Österreichischen Akademie der Wissenschaften, pp. 77-90.

Carsten, Janet (ed.) 2000. Cultures of Relatedness: New Approaches to the Study of Kinship. Cambridge: Cambridge University Press.

Dreyfus, Georges 1998. The Shuk-den Affair: History and Nature of a Quarrel. Journal of the International Association of Buddhist Studies, Vol. 21, No. 2, pp. 227270. Available at https://journals.ub.uni-heidelberg.de/index.php/jiabs/article/ view/8876/2783, last accessed on 18 March 2019.

Karmay, Samten G. 1998.The Arrow and the Spindle: Studies in History, Myths, Rituals, and Beliefs in Tibet. Kathmandu: Mandala.

Nebesky-Wojkowitz, Réne de 1993. Oracles and Demons of Tibet: The Cult and Iconography of the Tibetan Protective Deities. New Delhi: Book Faith India.

Punzi, Valentina 2013. Physical, Cultural and Religious Space in A myes bar dbon: Written and Oral Traditions of a gnas ri in Amdo. Revue d'Etudes Tibétaines, Vol. 26, pp. 93-114. Available at http://www.academia.edu/3684160/, last accessed on 10 December 2018.

Pommaret, Françoise 2012. On Local and Mountain Deities in Bhutan. Available at https://halshs.archives-ouvertes.fr/halshs-00717941/document, last accessed on 10 December 2018.

Phuntsho, Karma 2013. The History of Bhutan. New Delhi: Random House.

Sahlins, Marshall 2011. What Kinship Is (part one). Journal of the Royal Anthropological Institute, Vol. 17, No. 1, pp. 2-19. https://doi.org/10.1111/j.1467-9655.2010.01666.x.

Sahlins, Marshall 2013. What Kinship Is... And Is Not. Chicago: Chicago University Press.

Tucci, Giuseppe 1980 [1949]. Tibetan Painted Scrolls. Kyoto: Rinsen Co. 